\title{
The Analysis of Grammatical Shifts in Harry Potter "The Chamber of Secrets" Novel: A comparative Translational Study
}

\author{
Januari Rizki Pratama Rusman \\ Applied Linguistic \\ Yogyakarta State University \\ Yogyakarta, Indonesia \\ januaririzki.p.r@gmail.com
}

\author{
Pratomo Widodo \\ Applied Linguistic \\ Yogyakarta State University \\ Yogyakarta, Indonesia \\ pratomo@uny.ac.id
}

\begin{abstract}
The development of communication in this global era leads the improvement of the languages in the world. Then, language as the main tool of the communication holds a very important role in the human life. As the demand of global interaction, language becomes the most important thing that should be mastered. The language skills of people can be improved through many ways, one of them is by using the translational literary text. Novel as one of the literary products is very famous among the people in all around the world. Many people love to read and enjoy the story which is provided by novel. One of the most phenomenal products of novel was Harry Potter by J.K Rowling. Harry Potter has been published into many languages in the world, including in Indonesian. In Indonesia itself, this novel is very popular especially among teenagers and adults. Because its popularity and its complexity, the novel becomes the object of the research. This research aims to analyze the grammatical shifts which occur in the translation process of Harry Potter "The Chamber of Secret" as the source language (SL) in English and Harry Potter dan Kamar Rahasia as the target language (TL) in Indonesian. By analyzing the grammatical shifts, it is expected to make the comparison between English and Indonesian and finally it can make the language learners easier to learn those languages. This research is a descriptive qualitative research and uses tabulation method to collect the data from the novels. From the research, it is obtained the result that there are grammatical shifts in various percentage and number occur in the translation of the novel which consists of level shift, class shift, unit shift and the shift of the form of the words.
\end{abstract}

Keywords-grammatical shift; language comparisson; translational text.

\section{INTRODUCTION}

Translation study nowadays has become one of the most growing field of studies. Many students are interested in learning more about translation. Besides that, translation gives very prospective chances to be a real occupation. It is showed from the number of work fields that requires translation ability. In short, translation is very important and advantageous to be learned and to be mastered. Then, the discussion about translation absolutely cannot be separated from the language as a communicative aspect. So, there is strong relationship among translation, language, and communication. When the translators translate a translation product, they actually are trying to communicate with the target of translation product that they make. Translation is also about communication, because a translator will not be able to make a good translator product without a pretty communication skill. In communicating, language skill is absolutely needed. Language is an essential mean of communication among societies, and also it is a fundamental aspect in the culture expression and in the society [1].

Then, the demands from every aspect of life make translation become more crucial. The wider scope of communication from people brings the needs of language understanding from each people in every place especially interlanguage interaction.

\section{THEORETICAL REVIEW}

\section{A. Translation}

There are some experts that give the definition about translation. First is the definition that translation is about an effort to change the text from source language to the equal text in target language [2]. Another definition is quite similar which stated that translation is the replacement of textual material in one language (source language) by equivalent textual material in another language (target language) [3]. Then, another definition defined that translation is an activity which renders the meaning of a text into another language in the way that the author intended the text [4]. In general, experts agree that translation is a meaning transfer process and the change of meaning signs from one language to another language. Besides that, there are some types of translation, they are: intra-lingual translation, inter-lingual translation, and inter-semiotic translation [5]. Intra-lingual translation is a type of translation which transfer meaning from one meaning sign to another meaning sign but in one language. Inter-lingual translation is a type of translation which transfer meaning from one meaning sign to another meaning sign in different language and this type of translation is common known by public. Then, intersemiotic translation is a type of translation which transfer one 
meaning sign in different meaning sign. It means that, this type of translation transfers the meaning from one form to another different form.

Also, there are ten kinds of translation [6], they are: word to word translation, free translation, literal translation, esthetic poetic translation, dynamic translation, pragmatic translation, ethnographic translation, linguistic translation, communicative translation, and semantic translation. The various types of translation show that translation is a very dynamic field of study. In the other words, the scope of translation study is very broad and complex.

\section{B. Translation Shift}

Shift is almost occurs in every translation process. It reminds us that every language has its own linguistic system which makes the differences among them. Even, there are some language that has same language system (in term of grammar system, sentence structure, syntax rule) but also there some languages which have very different language system, and it cause the translation shift to be occurred. A shift is said to occur if, in a given TT, a translation equivalent other than the formal correspondent occurs for a specific source language element” [7].

Generally, there are two big groups of translation shift, they are level shift and category shift. Category shift consist of four sub types of shift, they are: structure shift, class shift, unit shift, and intra-system shift.

\section{Grammar and Grammatical Shift}

Grammar and translation is inseparable aspects. The position of grammar in language and translation is very important and it has crucial role. Grammar can be the identity of a language and it shows the characteristics of the languages.

\section{Translation Procedure}

For briefly explanation about translation, it will be more explained as the description below:

\section{1) Transference}

Transference (also known as emprunt, loan word, transcription) actually is a procedure of translation by transferring the words from source language (SL) to target language (TL) which uses borrowed words. This translation procedure is the same as Catford's transference and also it includes transliteration which relates to the conversion of different alphabets.

For example is the adjustment of alphabets (transliteration) from Russian (Cyrillic), Greek, Arabic, Chinese, Korean, Japanese, or Javanese into English. Despite of the denial from some groups of people about transference as a translation procedure, but according Newmark (1988) there is no other appropriate term to represent this thing. This thing happens of course because in one language cannot provide appropriate word which is equivalent with the target word, so it is really needed transference.

\section{2) Naturalisation} word.

Target language (TL) with the closest meaning of the

Here are the examThis type of translation procedure is a procedure which does some adjustments especially in phonological and morphological aspects from source language (SL). The point of this procedure is the adaptation of the word from source language (SL) to target language (TL) in phonological and morphological aspect so the result of the translation can be received and well understood by the readers in the target language.

\section{3) Cultural Equivalent}

Cultural equivalent is a procedure translation which adjust the meaning transferred in source language (SL) to target text (ST) especially in the cultural words in the target language.

\section{4) Functional equivalent}

Functional equivalent is a translation procedure which applies the cultural words in use to represent the word in source language (SL) to target language (TL) that sometimes requires culture-free words with a new specific term. This procedure of translation is a cultural componential analysis which is the most accurate way of translating that is deculturalising a cultural word.

\section{5) Descriptive equivalent}

Descriptive equivalent is a translation procedure which focuses on giving the equivalence descriptively. As the name, this procedure of translation tries to give description in every process of meaning transfer from source language (SL) to target language (TL). Descriptive equivalent as a translation procedure can be seen at the word 'machete' which is described as a 'Latin American Broad, heavy instrument', with the function is 'cutting or aggression'.

The second example is in the word 'Samurai' which is described as 'The Japanese aristocracy from the eleventh to the nineteenth century'; its function was 'to provide officers and administrators'. In this kind of translation procedure, the description and function are essential elements and very important in the explanation and therefore in translation. So, the thing that should be underlined is the presence of description and function in this in this kind of translation procedure.

\section{6) Synonymy}

As the common knowledge of people, synonymy can be understood as the similarity of the words. This procedure of translation tries to find the equivalence of the word from source language (SL) toples of synonymy:

Clever: Smart

\section{7) Through-Translation}

Through-Translation is a translation procedure which translates a word literary usually found in the translation of general collocation and the name of organization. Actually, this translation procedure is also known as Calque or loan 
translation. Completely, this type of translation can be found at the literary translations of common collocation, name of organization, the component of compounds and also in a phrase.

\section{8) Shifts or Transpositions}

A 'shift' (Catford's term) or 'transposition' (Vinay and Darbelnet) is a translation procedure involving a change in the grammar from source language (SL) to target language (TL). It means that, the shift or transposition which happens in the process of translation influences the change of the structure from the source language (SL) to target language (TL).

\section{9) Modulation}

Modulation is a kind of translation procedure which is related to the change of perspective, point of view, and also category of thought. The term 'modulation' to define 'a variation' through a change of viewpoint, of perspective (eclairage) and very often of category of thought'.

\section{0) Recognized translation}

Recognized translation is a kind of translation procedure which uses common and general translation method in translating a translation product.

\section{1) Translation label}

Translation label is a kind of translation which is very provisional. It is close with the use of "ial term that should be made with invert commas.

\section{2) Compensation}

Compensation is a type of translation procedure where the words in a sentence from source language (SL) are compensated with another part of sentence or contiguous sentence in a target language (TL). This kind of translation procedure usually occurs when a translator found in the process of translation that the sentence that loss of meaning, sound-effect, metaphor or pragmatic effect in one part of sentence.

\section{3) Componential analysis}

Componential analysis is a kind of translation procedure that analyzes the process of translation by separating lexical units into the analyzed component.

\section{4) Reduction and Expansion}

Reduction and expansion in translation procedure is the addition and reduction of a word in a translation process.

\section{5) Paraphrase}

Paraphrase is quite common used in a translation process where a translation will transfer a content of a text in source language (SL) to target language (TL) by adjusting the content of the text.

\section{E. Research Question}

Based on the background of the research, Research questions of this research are formulated as follow:

- What kind of grammatical shift that occurs on the translation of Harry Potter and The Chamber of Secrets and its translation in Indonesian?

- What cause the grammatical shift occurs on the translation of Harry Potter and The Chamber of Secrets and its translation in Indonesian?

\section{ReSEARCh MEthodology}

\section{A. Research Method}

This research used qualitative research method and content analysis method. It means that, the instrument of the research was the researcher and the data were taken by some aspects and criteria and after that they were analyzed by using some related theories [8].

\section{B. Method of Collecting data}

The data were collected manually by researcher. The technique of collecting data was by choosing, selecting, and eliminating the appropriate data [9]. The researcher read the book and observed carefully the sentence that might be an appropriate datum for the research. After that, the researcher took the sample of data and tabulated them. After the tabulation, the data were analyzed by using some related theories to the translation studies and translation shift, especially grammatical shift as the topic of the research. Researcher matched the data with some criteria with related to the characteristics of the translation shift as the topic of the research.

\section{Source of The Data}

The data were taken from Harry Potter and The Chamber of Secrets as the source text which English as the source language and its translation Harry Potter dan Kamar Rahasia as the target text which is Indonesian as the target language. The data taken were the shifts in grammatical aspect which consist of structure shift, unit shift, class shift, and intra-system shift.

\section{Result AND Discussion}

There are four shifts as a part of category shift related to grammar aspect, they areDenzin: structure shift, unit shift, class shift, and intra-system shift.

\section{1) Structure shift}

Structure shift is a part of category shift which concerns about the changes that occur in the structure level of the sentence. This type of shift consists of the change of the form of sentence from active form to passive form or vice versa, the change of the form of the sentence from negative form to positive form or vice versa, the change of the order of the word (syntax aspects) and also it can occur in the change of the form of the sentence such as from affirmative sentence to interrogative sentence or from affirmative sentence to imperative sentence, and so on. 
In the finding, the data found is generally about the change of passive and active form, or vice versa. For example, in the sentence He put the empty bowl back on the floor next to the cat-flap and lay back down on the bed, somehow even hungrier than he had been before the soup in English as source language and it is translated in Indonesian as target language becomes "Ditaruhnya mangkuk kosong itu di lantai di sebelah pintu kucing itu, lalu dia kembali berbaring di tempat tidurnya, malah lebih lapar daripada sebelum makan sup tadi." The sentence in source language is in active form and it becomes passive sentence in the target language.

In the source language, the pattern of the sentence indicates the active form of the sentence because the obvious pattern that is used. In forming the active sentence in English, it is usually used subject and verb 1 . Another way to form an active sentence in English is by using pattern subject + gerund and object. Then, to make a passive sentence in English, it is usually used the pattern subject+ to be+ verb 3 and it is followed by object or compliment. Actually, the making of passive sentence is easier than in Indonesian.

In English, the sign of passive sentence making is obvious. It is marked by the presence of to be before the verb (and the verb used is in past participle form / verb 3). Then, in Indonesian is quite different. The way to form passive sentence is more various than in English. The general pattern of the passive sentence making in Indonesian is by using the addition of prefix di- in the front of verb and usually the sentence is started by object. Sometimes, the position of object can be after the verb in the beginning of the sentence. As shown in the example, the sentence "ditaruhanya mangkuk kosong itu di lantai ...." the word "ditaruhnya" is the verb and it is located in the beginning of the sentence and it is followed by the "mangkok" as the object. The general pattern of the sentence in Indonesian is subject ${ }^{+}$predicate (verb) + object (+complimentary).

Generally, from the data which were found in the research, it showed that in English the use of active form is more dominant and in Indonesian is more dominant about the use of passive sentence.
TABLE I. STRUCTURE SHIFT IN THE TRANSLATION OF HARRY POTTER AND THE CHAMBER OF SECRETS FROM ENGLISH TO INDONESIAN.

\begin{tabular}{|c|c|c|c|}
\hline No. & English & Indonesian & Kind of shift \\
\hline 1. & $\begin{array}{l}\text { He put the empty } \\
\text { bowl back on the } \\
\text { floor next to the cat- } \\
\text { flap and lay back } \\
\text { down on the bed, } \\
\text { somehow even } \\
\text { hungrier than he had } \\
\text { been before the } \\
\text { soup. }\end{array}$ & $\begin{array}{l}\text { Ditaruhnya mangkuk } \\
\text { kosong itu di lantai di } \\
\text { sebelah pintu kucing itu, } \\
\text { lalu dia kembali berbaring } \\
\text { di tempat tidurnya, malah } \\
\text { lebih lapar daripada } \\
\text { sebelum makan sup tadi. }\end{array}$ & Structure Shift \\
\hline 2. & $\begin{array}{l}\text { Sending the family } \\
\text { servant to stop Harry } \\
\text { going back to } \\
\text { Hogwarts also } \\
\text { sounded exactly like } \\
\text { the sort of thing } \\
\text { Malfoy would do. }\end{array}$ & $\begin{array}{l}\text { Mengirim pelayan rumah } \\
\text { untuk mencegah Harry } \\
\text { kembai ke Hogwarts } \\
\text { kelihatannya juga jenis hal } \\
\text { yang akan dilakukan } \\
\text { Malfoy. }\end{array}$ & Structure Shift \\
\hline 3. & $\begin{array}{l}\text { "Flying an illegal car } \\
\text { halfway across the } \\
\text { country - anyone } \\
\text { could have seen you- } \\
\text { “... }\end{array}$ & $\begin{array}{l}\text { Menerbangkan mobil } \\
\text { ilegal,menyeberang separo } \\
\text { negeri - bisa kelihatan } \\
\text { siapa saja. ...” }\end{array}$ & Structure Shift \\
\hline 4. & $\begin{array}{l}\text {. . . ., Harry - orang } \\
\text { itu tahu segalanya. }\end{array}$ & $\begin{array}{l}\text {...., Harry - doesn't miss } \\
\text { a trick, that man. }\end{array}$ & Structure Shift \\
\hline 5. & $\begin{array}{l}\text { "I thought you were } \\
\text { going to buy me a } \\
\text { present." }\end{array}$ & $\begin{array}{l}\text {... “ katanya aku akan } \\
\text { diberikan hadiah.” }\end{array}$ & Structure Shift \\
\hline 6. & $\begin{array}{l}\ldots . . \text { for Mr. Borgin } \\
\text { to read. }\end{array}$ & $\begin{array}{l}\text {... . untuk dibaca Mr. } \\
\text { Borgin. }\end{array}$ & Structure Shift \\
\hline 7. & $\begin{array}{l}\text { The name Malfoy } \\
\text { still commands a } \\
\text { certain respect , . . . }\end{array}$ & $\begin{array}{l}\text { Nama Malfoy masih } \\
\text { dihormati, . . . }\end{array}$ & Structure Shift \\
\hline 8. & $\begin{array}{l}\text { "Yeh should've } \\
\text { ignored him, } \\
\text { Arthur,"... }\end{array}$ & $\begin{array}{l}\text { "Kau seharusnya jangan } \\
\text { acuhkan dia, Arthur,”. . . }\end{array}$ & Structure Shift \\
\hline 9. & $\begin{array}{l}\text { George had } \\
\text { forgotten his box of } \\
\text { Filibuster fireworks. }\end{array}$ & $\begin{array}{l}\text { Kembang api Filibuster } \\
\text { George ketinggalan. }\end{array}$ & Structure Shift \\
\hline 10. & $\begin{array}{l}\text { This wasn't nearly as } \\
\text { uncomfortable as } \\
\text { using Flo powder. }\end{array}$ & $\begin{array}{l}\text { Ini lebih nyaman } \\
\text { disbanding menggunakan } \\
\text { bubuk Floo. }\end{array}$ & Structure Shift \\
\hline 11. & $\begin{array}{l}\text { "I think the feast's } \\
\text { already started,”said } \\
\text { Ron,. . . . }\end{array}$ & $\begin{array}{l}\text { “Kurasa pestanya sudah } \\
\text { mulai”, kata Ron, . . . }\end{array}$ & Structure Shift \\
\hline
\end{tabular}

\section{2) Unit shift}

Unit shift is a part of category shift. It is showed by the addition or the reduction from the number of words in source language to target language. For simple example, one word in source language can be translated into two or three words in the target language or vice versa. It depends on the system of the word that is used in each language. Also, it is also related with grammar. Every changing in each word is influenced by grammar in each language system.

The data found in the research about unit shift were shown in the table below: 
TABLE II. UNIT SHIFT IN THE TRANSLATION OF HARRY POTTER AND THE CHAMBER OF SECRETS FROM ENGLISH TO INDONESIAN.

\begin{tabular}{|c|l|l|c|}
\hline No. & \multicolumn{1}{|c|}{ English } & \multicolumn{1}{|c|}{$\begin{array}{c}\text { Indonesian } \\
\text { shift }\end{array}$} \\
\hline 1. & $\begin{array}{l}\text { Ron had gone a nasty } \\
\text { greenish color, his } \\
\text { eyes fixed on the } \\
\text { house. }\end{array}$ & $\begin{array}{l}\text { Wajah Ron berubah } \\
\text { pucat, matanya terpaku } \\
\text { ke rumah. }\end{array}$ & Unit shift \\
\hline 2. & $\begin{array}{l}\text { M. . And old } \\
\text { Mundungus Fletcher } \\
\text { tried to put a hex on } \\
\text { me when I had my } \\
\text { back turned. . }\end{array}$ & $\begin{array}{l}\text { Fletcher mencoba } \\
\text { menyihirku ketika aku } \\
\text { berbalik. .. }\end{array}$ & Unit shift \\
\hline 3. & $\begin{array}{l}\text { She rose out of it with } \\
\text { an angry screech and } \\
\text { sped off toward the } \\
\text { castle without a } \\
\text { backward look. }\end{array}$ & $\begin{array}{l}\text { Burung hantu betina itu } \\
\text { terbang keluar dengan } \\
\text { jeritan marah dan terbang }\end{array}$ & Unit shift \\
\hline 4. & $\begin{array}{l}\text { Intrigued, Harry } \\
\text { flicked the envelope } \\
\text { open and pulled out } \\
\text { the sheaf of parchment } \\
\text { inside. }\end{array}$ & $\begin{array}{l}\text { Tergugah rasa ingin } \\
\text { tahunya, Harry membuka } \\
\text { amplop itu dan menarik } \\
\text { keluar setumpuk } \\
\text { perkamen dari dalamnya. }\end{array}$ & Unit shift \\
\hline 5. & $\begin{array}{l}\text { Harry’s stomach gave } \\
\text { a horrible lurch. }\end{array}$ & Hati Harry mencelos. & Unit shift \\
\hline 6. & He shouted, . . & Teriaknya, ... & Unit shift \\
\hline 7. & Slow on the uptake. & Telmi & Unit shift \\
\hline
\end{tabular}

\section{3) Class shift}

As the name, class shift is the change of class of the word. The word in source language which is actually a noun can be a verb, an adjective, or an adverb in the target language. The class shift occur usually because the translator tries to find the best acceptable equivalent in the target language, so the translator should make a change and adjust the form of the word. In making the acceptable translation, the translator should adjust the suitable equivalence from each word in source language and target language. That adjustment makes the shift in word level, especially in class of the word level.

Some data found in the research about class shift in the novel as shown in the table below:

TABLE III. CLASS SHIFT IN THE TRANSLATION OF HARRY POTTER AND THE CHAMBER OF SECRETS FROM ENGLISH TO INDONESIAN.

\begin{tabular}{|c|c|c|c|}
\hline $\begin{array}{c}\text { No } \\
\text {. }\end{array}$ & English & Indonesian & $\begin{array}{c}\text { Kind of } \\
\text { shift }\end{array}$ \\
\hline 1. & $\begin{array}{l}\ldots . ., \text { and the grass } \\
\text { needed cutting }-\ldots .\end{array}$ & $\begin{array}{l}\text {...., rumputnya perlu } \\
\text { dipotong... }\end{array}$ & Class shift \\
\hline 2. & $\begin{array}{l}\text { "can’t hear a thing," } \\
\text { he said tensely. }\end{array}$ & $\begin{array}{l}\text { "tidak kedengaran apa- } \\
\text { apa”, katanya tegang. }\end{array}$ & Class shift \\
\hline 3. & $\begin{array}{l}\text {.”Kau tak apa-apa?” } \\
\text { Tanya Harry cemas. }\end{array}$ & $\begin{array}{l}\text { “Are you okay?” said } \\
\text { Harry urgently }\end{array}$ & Class shift \\
\hline 4. & $\begin{array}{l}\text { It had snapped, almost } \\
\text { into two;... . }\end{array}$ & $\begin{array}{l}\text { Tongkat itu patah, nyaris } \\
\text { jadi dua. }\end{array}$ & Class shift \\
\hline 5. & $\begin{array}{l}\text { “Aaargh!” said Ron as } \\
\text { another twisted limb } \\
\text { punched a large dent } \\
\text { into his door;. . . }\end{array}$ & $\begin{array}{l}\text { “Aaaargh!” jerit Ron } \\
\text { ketika dahan bengkok } \\
\text { lain menghantam pintu } \\
\text { mobilnya sampai } \\
\text { melesak. }\end{array}$ & Class shift \\
\hline 6. & $\begin{array}{l}\text { Ginny was among } \\
\text { them, easily visible } \\
\text { because of her vivid } \\
\text { Weasley hair. }\end{array}$ & $\begin{array}{l}\text { Ginny berada di antara } \\
\text { mereka, mudah } \\
\text { ditemukan karena } \\
\text { rambut Weasley-nya } \\
\text { yang merah mencolok. }\end{array}$ & Class shift \\
\hline
\end{tabular}

\begin{tabular}{|c|l|l|c|}
\hline 7. & $\begin{array}{l}\text { There was a long } \\
\text { silence. }\end{array}$ & Sunyi lama sekali & Class shift \\
\hline 8. & $\begin{array}{l}\text { "Can you believe our } \\
\text { luck, though?” said } \\
\text { Ron . . . . }\end{array}$ & $\begin{array}{l}\text { "Nasib kita sungguh sulit } \\
\text { dipercaya, ya?” kata } \\
\text { Ron. . . }\end{array}$ & Class shift \\
\hline 9. & "Gave you the bug. ... & $\begin{array}{l}\text { "Kau langsung } \\
\text { ketularan. . }\end{array}$ & Class shift \\
\hline 10. & $\begin{array}{l}\text { Lockhart cleared his } \\
\text { throat and loudly and } \\
\text { silence fell. }\end{array}$ & $\begin{array}{l}\text { Lockhart berdehem } \\
\text { keras-keras dan seluruh } \\
\text { kelas diam. }\end{array}$ & Class shift \\
\hline 11. & $\begin{array}{l}\text { "sweeps the board } \\
\text { with them.” }\end{array}$ & $\begin{array}{l}\text { "paling cocok untuk } \\
\text { menyapu lantai”. }\end{array}$ & Class shift \\
\hline
\end{tabular}

\section{4) Intra-system shift}

Intra-system shift in the data research from the novel is about the change of singular-plural form.

TABLE IV. INTRA-SYSTEM SHIFT IN THE TRANSLATION OF HARRY POTTER AND THE CHAMBER OF SECRETS FROM ENGLISH TO INDONESIAN.

\begin{tabular}{|c|c|c|c|}
\hline $\begin{array}{c}\text { No } \\
\text {. }\end{array}$ & English & Indonesian & $\begin{array}{c}\text { Kind of } \\
\text { shift }\end{array}$ \\
\hline 1. & $\begin{array}{l}\text { Moonlight was } \\
\text { shining through the } \\
\text { bars on the window. }\end{array}$ & $\begin{array}{l}\text { Cahaya bulan menerobos } \\
\text { masuk lewat jeruji } \\
\text { jendela. }\end{array}$ & $\begin{array}{c}\text { Intra- } \\
\text { system shift }\end{array}$ \\
\hline 2. & $\begin{array}{l}\text { Harry had heard these } \\
\text { rumors about } \\
\text { Malfoy's family } \\
\text { before, and they didn't } \\
\text { surprise him at all. }\end{array}$ & $\begin{array}{l}\text { Harry tak pernah } \\
\text { mendengar desas-desus } \\
\text { tentang keluarga Malfoy } \\
\text { sebelumnya, dan ini } \\
\text { sama sekali tidak } \\
\text { mengejutkannya. }\end{array}$ & $\begin{array}{c}\text { Intra- } \\
\text { system shift }\end{array}$ \\
\hline 3. & $\begin{array}{l}\text { But really" (she was } \\
\text { now adding three fried } \\
\text { eggs to his plate),.... }\end{array}$ & $\begin{array}{l}\text { Tapi sungguh } \\
\text { kelewatan,”(sekarang dia } \\
\text { menambahkan tiga telur } \\
\text { goreng ke piring Harry) }\end{array}$ & $\begin{array}{c}\text { Intra- } \\
\text { system shift }\end{array}$ \\
\hline 4. & $\begin{array}{l}\text { "It will be for } \\
\text { Professor McGonagall } \\
\text { to decide on these } \\
\text { boys’ punishments, } \\
\text { Severus," said } \\
\text { Dumbledore calmly. }\end{array}$ & $\begin{array}{l}\text { "Professor McGonagall- } \\
\text { lah yang berhak } \\
\text { memutuskan hukuman } \\
\text { untuk anak-anak ini, } \\
\text { Severus,” kata } \\
\text { Dumbledore tenang. }\end{array}$ & $\begin{array}{c}\text { Intra- } \\
\text { system shift }\end{array}$ \\
\hline 5. & $\begin{array}{l}\text {..., burst into flames } \\
\text { and curled into ashes. }\end{array}$ & $\begin{array}{l}\text {...., menyala, lalu } \\
\text { tergulung menjadi abu. }\end{array}$ & $\begin{array}{c}\text { Intra- } \\
\text { system shift }\end{array}$ \\
\hline 6. & $\begin{array}{l}\text { Ron was having far } \\
\text { worse problems. }\end{array}$ & $\begin{array}{l}\text { Ron menghadapi } \\
\text { masalah yang lebih } \\
\text { parah. }\end{array}$ & $\begin{array}{c}\text { Intra- } \\
\text { system shift }\end{array}$ \\
\hline 7. & $\begin{array}{l}\text { You may find } \\
\text { yourselves facing your } \\
\text { worst fears in this } \\
\text { room. }\end{array}$ & $\begin{array}{l}\text { Kalian mungkin akan } \\
\text { menghadapi ketakutan } \\
\text { terbesar kalian di } \\
\text { ruangan ini. }\end{array}$ & $\begin{array}{c}\text { Intra- } \\
\text { system shift }\end{array}$ \\
\hline 8. & $\begin{array}{l}\text { “Givin’ me advice on } \\
\text { getting' kelpies out of } \\
\text { a well,” . . . . }\end{array}$ & $\begin{array}{l}\text { "beri aku nasihat } \\
\text { keluarkan kelpie dari } \\
\text { sumur," . . . . }\end{array}$ & $\begin{array}{c}\text { Intra- } \\
\text { system shift }\end{array}$ \\
\hline 9. & $\begin{array}{l}\text { Wooden filing } \\
\text { cabinets stood around } \\
\text { the walls; .... }\end{array}$ & $\begin{array}{l}\text { Lemari arsip dari kayu } \\
\text { berderet di sekeliling } \\
\text { ruangan. }\end{array}$ & $\begin{array}{c}\text { Intra- } \\
\text { system shift }\end{array}$ \\
\hline
\end{tabular}

\section{CONCLUSION}

Based on the analysis of data from the research, there are some conclusions that can be concluded that there are grammatical shifts found in the translation of Harry Potter and the Chamber of Secrets, from English to Indonesian. The grammatical shifts found in the novel consist of level shift, structure shift, class shift, category shift and intra-system shift. 
Then, there are some factors that influence and make grammatical shifts occur, such as: the difference of language system of each language, the different of culture from each language, and the difference of linguistic aspect and linguistic rules in each language.

\section{ACKNOWLEDGMENT}

The researchers want to say thank you to every people who had helped the researcher in doing this research. Special thanks to Indonesian Endowment Fund for Education (LPDP) for giving full funding and scholarship for Januari Rizki Pratama Rusman to study at Applied Linguistic program, Graduated School Program, Yogyakarta State University.

\section{REFERENCES}

[1] A. Sirbu, "The significance of language as a tool of communication," Nav. Acad. Scient. Bull., vol. 18, no. 2, pp. 405-406, 2015.

[2] R. Machali, Pedoman bagi penerjemah [Guidance for translators]. Bandung: Kaifa, 2009, pp. 26.

[3] P. Newmark, A textbook of translation. London: Prentice-Hall International, 1988, p. 5.

[4] J. C. Catford, A linguistic theory of translation. London: Oxford University Press, 1965, p. 20.

[5] J. Munday, Introducing translation studies (theories and applications). USA and Canada: Routledge, 2012, pp. 8-9.

[6] M. R. Nababan, Teori menerjemah bahasa Inggris [English translating theories]. Yogyakarta: Pustaka Pelajar, 2003, p. 15.

[7] M. D. S. Simatupang, Pengantar teori penerjemahan [Introduction to translation theories]. Jakarta: Dirjendikti, 2009, pp. 29-44.

[8] Kardimin. Pintar menerjemah (wawasan teoritik dan praktek) [Smart in translating (theoretical and practical insight)]. Yogyakata: Pustaka Pelajar, 2013, p. 41.

[9] N. K. Denzin and Y. S. Lincoln. Handbook of qualitative research. Yogyakarta: Pustaka Pelajar, 2009, p. 98. 